\title{
Upaya Meningkatkan Kemampuan Pemahaman Konsep Matematika Siswa dengan Menggunakan Model Pembelajaran Kooperatif Tipe Numbered Heads Together (NHT) pada Kelas VIII SMP Bhakti Nusantara Jakarta
}

\author{
Nur Meilani Astuti, ${ }^{1, a)}$, Aris Hadiyan Wijaksana ${ }^{2, b)}$, Ratna Widyati ${ }^{3, c)}$ \\ ${ }^{1}$ Program Studi Pendidikan Matematika FMIPA Universitas Negeri Jakarta, Rawamangun, Jakarta Timur 13220 \\ ${ }^{3}$ Program Studi Ilmu Komputer FMIPA Universitas Negeri Jakarta, Rawamangun, Jakarta Timur 13220 \\ Email penulis: ${ }^{a)}$ nurmeilaniastuti95@gmail.com, b) arishadiyan@ gmail.com, ${ }^{\mathrm{c})}$ ratna.widyati@gmail.com
}

\begin{abstract}
This research is class action research aimed at enhancing the students understanding mathematical concepts using NHT cooperative learning model in class VIII-1 SMP Bhakti Nusantara Jakarta. The study was implemented in 3 cycles. The NHT cooperative learning model consists of five phases, they are: Numbering phase, questioning phase, heads together phase, call out phase and answering phase. The final test score for understanding the mathematical concepts of SP1 in cycle I was 78.6, in cycle II became to 82.1, in cycle III increased to 85.7. SP2 in cycle I was 71,4 , in cycle II became to 75 , in cycle III increased to 92,9 . SP3 in cycle I was 57,1 , in cycle II became to 67,9 , in cycle III increased to 75 . SP4 in cycle I was 67,9 , in cycle II became to 78,6 , in cycle III increased to 82,1 . SP5 in cycle I was 46,4 , in cycle II became to 71,4 , in cycle III increased to 85,7 . SP6 in cycle I was 57,1 , in cycle II became to 60,8 , in cycle III increased to 75 . So, it can be concluded that the application of the NHT cooperative model can increase the student's ability in understanding mathematical concepts.
\end{abstract}

Keywords: Numbered Heads Together Cooperative Learning Model,The Student's Ability in Understanding The Matematichal Concepts

\begin{abstract}
Abstrak
Penelitian ini merupakan penelitian tindakan kelas (PTK) yang bertujuan untuk meningkatkan kemampuan pemahaman konsep matematika siswa dengan menggunakan model pembelajaran kooperatif NHT di kelas VIII1 SMP Bhakti Nusantara Jakarta. Penelitian ini dilaksanakan dalam tiga siklus. Model pembelajaran kooperatif NHT terdiri dari 5 tahap, yaitu: tahap numbering, tahap questioning, tahap heads together, tahap call out dan tahap answering. Nilai tes akhir pemahaman konsep matematika SP1 pada siklus I memperoleh nilai 78,6, pada siklsu II meningkat menjadi 82,1, pada siklus III meningkat menjadi 85,7. SP2 pada siklus II memperoleh nilai 71,4, pada siklsu II meningkat menjadi 75, pada siklus III meningkat menjadi 92,9. SP3 pada siklus I memperoleh nilai 57,1, pada siklsu II meningkat menjadi 67,9, pada siklus III meningkat menjadi 75 . SP4 pada siklus I memperoleh nilai 67,9, pada siklsu II meningkat menjadi 78,6, pada siklus III meningkat menjadi 82,1. SP5 pada siklus I memperoleh nilai 46,4, pada siklsu II meningkat menjadi 71,4, pada siklus III meningkat menjadi 85,7. SP6 pada siklus I memperoleh nilai 57,1, pada siklsu II meningkat menjadi 60,8, pada siklus III meningkat menjadi 75. Sehingga dapat disimpulkan bahwa penerapan model pembelajaran kooperatif tipe NHT dapat meningkatkan kemampuan pemahaman konsep matematika.
\end{abstract}

Kata kunci: Model Pembelajaran Kooperatif Numbered Heads Together, Kemampuan Pemahaman Konsep Matematika

Copyright (c) 2020 Astuti, Wijaksana, Widyati

$\triangle$ Corresponding author:

Email Address: nurmeilaniastuti95@gmail.com

Received 3 Februari 2020, Accepted 10 Februari 2020, Published 20 Februari 2020

https://doi.org/10.21009/jrpmj.v2i1.12124

\section{LATAR BELAKANG}


Matematika adalah ilmu pengetahuan yang ada pada semua jenjang pendidikan, mulai dari tingkat dasar sampai tingkat perguruan tinggi. Matematika memegang peranan penting dalam mendidik siswa serta melatih pola pikir siswa untuk berpikir logis, rasional dan kritis (Danti, dkk., 2015). Dengan mempelajari matematika, seseorang diharapkan dapat berpikir logis, sistematis, kritis, dan kreatif serta dapat menguasai materi matematika yang telah diberikan di sekolah. Sehubungan dengan hal tersebut, maka pembelajaran matematika perlu diajarkan kepada para siswa dengan sebaik mungkin agar dapat dipahami secara optimal.

Mengacu pada Departemen Pendidikan Nasional tahun 2007, menyatakan bahwa pelajaran matematika bertujuan agar siswa memiliki kemampuan : (1) memahami konsep matematika; (2) menggunakan penalaran pada pola dan sifat; (3) memecahkan masalah, merancang model matematika, menyelesaikan model, dan menafsirkan solusi yang diperoleh; (4) mengkomunikasikan gagasan dengan symbol, tabel, diagram atau media lain untuk memperjelas keadaan atau masalah; (5) memiliki sikap menghargai kegunaan matematika dalam kehidupan.

Pemahaman konsep matematika memegang peranan penting dalam pembelajaran matematika. Begitu penting dalam pembelajaran matematika, maka pemahaman konsep perlu ditingkatkan. Pemahaman konsep yang rendah mengakibatkan rendahnya nilai matematika siswa. Kemampuan pemahaman konsep juga merupakan salah satu hal penting yang harus dimiliki siswa dalam belajar matematika. Karena konsep dalam matematika memiliki keterkaitan satu sama lain. Kesulitan siswa dalam memahami konsep matematika, tentunya akan memengaruhi kemampuan matematika lainnya. Bisa kita pahami bahwa siswa tidak dapat melanjutkan pembelajaran matematika selanjutnya tanpa memahami konsep matematika tersebut terlebih dahulu. Hal ini menunjukkan bahwa pemahaman konsep matematika sangatlah penting sehingga perlu untuk ditingkatkan.

Berdasarkan hasil observasi yang dilakukan di kelas VIII-1 SMP Bhakti Nusantara Jakarta ketika kegiatan belajar mengajar berlangsung, beberapa siswa tidak fokus dalam pembelajaran matematika dan cenderung masih ramai. Hasil observasi yang dilakukan di SMP Bhakti Nusantara Jakarta kelas VIII-1 terhadap keadaan kelas dalam pembelajaran matematika terlihat guru cenderung menggunakan metode pembelajaran ceramah dan kurang memberikan kesempatan kepada siswa untuk aktif dalam pembelajaran, perhatian siswa terhadap guru masih belom fokus sepenuhnya, beberapa siswa terlihat kurang aktif dalam pembelajaran, siswa kurang percaya diri terhadap kemampuannya. Hal tersebut terlihat pada saat mengerjakan soal yang diberikan oleh guru, beberapa siswa melihat hasil pekerjaan temannya atau mencocokkannnya.

Sementara itu berdasarkan hasil wawancara, guru pengampu matematika menyatakan bahwa kemampuan pemahaman konsep matematika siswa di kelas tersebut masih rendah. Hal ini didukung oleh data yang didapat melalui tes pra penelitian pemahaman konsep matematika siswa kelas VIII-1 SMP Bhakti Nusantara. Berikut hasil tes pra penelitian. 
Tabel 1 Nilai Tes Pra Penelitian

\begin{tabular}{|c|c|}
\hline Nilai & Banyak siswa \\
\hline$\leq 10.9$ & - \\
\hline $11-14.9$ & - \\
\hline $15-19.9$ & - \\
\hline $20-29.9$ & 7 \\
\hline $30-39.9$ & 9 \\
\hline $40-49.9$ & 9 \\
\hline $50-59.9$ & 2 \\
\hline $60-69.9$ & 1 \\
\hline $70-79.9$ & - \\
\hline $80-89.9$ & - \\
\hline
\end{tabular}

Rendahnya kemampuan pemahaman konsep matematika siswa ditunjukkan oleh hasil tes pra penelitian yang tertera pada tabel di atas. Dari hasil tes menunjukkan siswa masih kurang dalam memahami konsep matematika. Proses pembelajaan di kelas perlu diperbaiki guna meningkatkan pemahaman konsep matematika siswa. Perbaikan proses pembelajaran perlu adanya penerapan model pembelajaran baru yang dapat meningkatkan proses pembelajaran di kelas. Diperlukan upaya guru untuk menciptakan kondisi pembelajaran yang dapat memaksimalkan proses pembelajaran. Maka melalui penelitian tindakan kelas ini akan diterapkan suatu model pembelajaran yang diharapkan dapat mengkondisikan siswa sedemikian rupa sehingga dapat terlibat aktif dalam pembelajaran serta menemukan dan memahami suatu konsep matematika melalui diskusi kelompok. Model pembelajaran yang digunakan adalah model pembelajaran kooperatif tipe Numbered Heads Together (NHT).

Model pembelajaran kooperatif merupakan model pembelajaran dimana para siswa bekerja dalam kelompok-kelompok kecil. Model Numbered Heads Together (NHT) merupakan salah satu model pembelajaran kooperatif dimana pelakasanaannya dilakukan dengan membentuk siswa menjadi beberapa kelompok dalam kegiatan pembelajaran yang pembagian kelompoknya dilakukan secara heterogen. Pembagian kelompok secara heterogen ini dengan tujuan agar siswa dapat saling bekerjasama apabila mengalami kesulitan, saling bertukar pendapat dalam menyelesaikan soal atau masalah yang diberikan pada masing-masing kelompok. Siswa dibentuk dalam tiga tingkatan kelas yaitu kelas atas, kelas menengah dan kelas bawah. Masing-masing kelompok diberi nomor sebanyak anggota kelompok sehingga masing-masing anggota kelompok memiliki nomor yang berbeda-beda. Kemudian masing-masing kelompok diberikan tugas atau soal untuk dikerjakan secara berkelompok dalam mengerjakan tugas yang telah diberikan dengan cara saling berdiskusi atau bertukar pikiran dengan anggota kelompoknya dalam menyelesaikan tugas atau soal tersebut.

Pembelajaran model kooperatif tipe Numbered Heads Together (NHT) diharapkan dapat menjadikan pembelajaran matematika menjadi lebih menarik dan siswa lebih aktif secara positif dalam pembelajaran seperti berdiskusi dan menjawab soal, baik tehadap guru maupun terhadap temannya. Siswa yang bersikap aktif dan positif dalam pembelajaran, memungkinkan hasil yang baik dalam pembelajaran. Pembelajaran model kooperatif tipe Numbered Heads Together (NHT) dapat merubah 
kebiasaan siswa di dalam kelas terhadap hal-hal yang bersifat negatif seperti membuat kegaduhan di dalam kelas sehingga pembelajaran akan lebih efektif dan hasil yang diharapkan dapat tercapai

\section{KAJIAN PUSTAKA:}

\section{Pemahaman konsep matematika}

Pemahaman konsep merupakan suatu aspek yang sangat penting dalam proses pembelajaran, karena dengan memahami konsep peseta didik dapat mengembangkan kemampuannya dalam setiap materi pembelajaran. Penguasaan konsep matematika mutlak diperlukan dan harus dipahami dengan benar sejak dini. Hal ini karena konsep-konsep dalam matematika merupakan suatu rangkaian sebab akibat. Menurut Cahya dalam Riski dkk (2014) suatu konsep disusun berdasarkan konsep-konsep sebelumnya dan akan menjadi dasar bagi konsep-konsep selanjutnya, sehingga pemahaman yang salah terhadap suatu konsep, akan berakibat pada kesalahan pemahaman terhadap konsep-konsep selajutnya.

Pemahaman dalam KBBI adalah kemampuan seseorang atau sekelompok orang untuk mengerti sesuatu secara benar. Menurut Sudijono (2011), pemahaman atau comprehension adalah kemampuan seseorang untuk mengerti atau memahami sesuatu setelah sesuatu itu diketahui dan diingat. Pemahaman menurut Dimyati dan Mudijiono (2010) mencangkup kemampuan menangkap arti, dan makna tentang hal yang dipelajari. Sanjaya (2008) juga mengatakan bahwa pemahaman berkenaan dengan kemampuan menjelaskan, menerangkan, menafsirkan atau kemampuan menangkap makana, atau arti suatu konsep.

Berdasarkan beberapa pendapat tentang pemahaman, dapat disimpulkan bahwa pemahaman adalah kemampuan seseorang untuk mengerti atau memahami sesuatu setelah diketahui dan diingat, memahami atau mengerti apa yang diajarkan, dan dapat mengutarakan kembali apa yang dipelajari dengan kalimatnya sendiri. Jadi seseorang dikatakan memahami sesuatu apabila ia dapat memberikan penjelasan yang lebih rinci tentang hal itu dengan menggunakan kata-katanya sendiri.

Konsep menurut KBBI adalah ide atau pengertian yang diabstrakkan dari peristiwa konkret. Konsep dapat didefinisikan sebagai suatu gagasan/ide yang relatif sempurna dan bermakna (Amri, 2013). Winkel (2007) menyatakan bahwa konsep adalah sebagai suatu sistem satuan arti yang mewakili sejumlah objek yang mempunyai ciri-ciri yang sama. Jadi dari uraian di atas dapat disimpulkan konsep adalah abstraksi yang mewakili suatu objek dari peristiwa konkret yang memiliki kesamaan ciri yang relatif sempurna dan bermakna.Dengan demikian pemahaman konsep dapat diartikan kemampuan seseorang terhadap sesuatu dengan cara membangun hubungan antara pengetahuan awal dengan pengetahuan baru yang memiliki keterkaitan atau ciri yang sama.

Pemahaman konsep penting bagi siswa karena dengan memahami konsep yang benar maka siswa dapat menyerap, menguasai, dan menyimpan materi yang dipelajari dalam jangka waktu yang lama. Pemahaman konsep matematika juga dapat menjadi modal awal penyelesaian dari soal-soal matematika dan dianggap mampu dalam mendukung penyelesaian persoalan sehari-hari. Adapun 
indikator untuk menunjukkan kemampuan pemahaman konsep menurut kemendikbud antara lain yaitu: menyatakan ulang konsep, mengklasifikasikan objek menurut sifat-sifat tertentu sesuai dengan konsepnya, memberi contoh dan bukan contoh dari suatu konsep, menyajikan konsep dalam berbagai bentuk representasi matematis, mengembangkan syarat perlu atau syarat cukup dari suatu konsep, menggunakan dan memanfaatkan serta memilih prosedur atau operasi tertentu, mengaplikasikan konsep dan algoritma dalam pemecahan masalah.

\section{METHOD}

\section{Jenis Penelitian}

Jenis penelitian ini adalah penelitian tindakan kelas atau lebih dikenal dengan classroom action research. Penelitian tindakan kelas adalah penelitian yang memaparkan terjadinya sebab akibat dari perlakuan, sekaligus memaparkan apa saja yang terjadi ketika perlakuan diberikan, dan memaparkan seluruh proses sejak awal pemberian perlakuan sampai dengan dampak dari perlakuan tersebut (Suhasurmi, dkk., 2015). Menurut Kardiawarman dalam Paizaluddin dan Ermalinda (2015) penelitian tindakan kelas merupakan penelitian yang dilakukan pada sebuah kelas untuk mengetahui akibat tindakan yang diterapkan pada suatu subyek penelitian di kelas tersebut. Penelitian tindakan kelas merupakan bagian dari penelitian tindakan yang dilakukan oleh guru atau dosen di dalam kelas (sekolah atau perguruan tinggi) tempat ia mengajar yang bertujuan untuk memperbaiki dan meningkatkan kualitas dan kuantitas dari proses pembelajaran yang berlangsung di dalam kelas (Iskandar, 2012).

Penelitian tindakan kelas dilakukan secara kolaboratif (partisipatoris), yaitu antara peneliti, guru kelas dan observer menjadi satu tim. Penelitian tindakan kelas berlangsung dalam siklus-siklus penelitian yang terdiri dari empat tahap. Adapun keempat tahapan tersebut adalah perencanaan, pelaksanaan, analisis dan refleksi (Kunandar, 2011). Apabila dalam siklus terakhir masih belum maksimal terjadi perubahan yang diharapkan, maka siklus akan terus diulang. Penelitian dapat dilakukan lebih dari tiga siklus apabila pada tiap siklus masih belum tejadi perubahan yang diharapkan sesuai dengan hasil evaluasi pada siklus sebelumnya. Penelitian ini dapat diakhiri jika ada data mengenai kemampuan pemahaman konsep matematika telah mengalami peningkatan yang stabil.

\section{Subjek Penelitian}

Penelitian ini akan dilakukan terhadap seluruh siswa kelas VIII-1 SMP Bhakti Nusantara Jakarta yang berjumlah 28 siswa. Namun, karena keterbatasan peneliti dalam melakukan pengamatan, maka peneliti akan memilih enam orang siswa yang memiliki kemampuan berbeda yang dijadikan subjek penelitian. Subjek penelitian terdiri dari dua orang siswa kelompok atas, dua orang siswa kelompok menengah, dan dua orang siswa kelompok bawah yang dipilih berdasarkan diskusi dengan guru matematika di kelas dan hasil tes prapenelitian kemampuan pemahaman konsep siswa yang diselenggarakan saat observasi awal. 


\section{Teknik Pengumpulan Data}

Teknik pengumpulan data adalah cara-cara yang dapat digunakan oleh peneliti untuk mengumpulkan data yang berkaitan dengan siswa dan proses belajar mengajar di kelas penelitian. Beberapa data yang akan dikumpulkan diantaranya :

1. Data tes awal kemampuan pemahaman konsep matematika siswa yang diperoleh dari tes prapenelitian kemampuan pemahaman konsep matematika.

2. Data kemampuan pemahaman konsep matematika siswa yang diperoleh dari hasil lembar kerja siswa dan kemampuan pemahaman konsep matematika siswa di setiap akhir sklus.

3. Data hasil pengamatan selama proses pembelajaran berlangsung diperoleh dari lembar catatan lapangan.

4. Hasil wawancara.

5. Dokumentasi aktivitas belajar mengajar selama pembelajaran berlangsung pada setiap kegiatan.

\section{Analisis Data}

Menurut Patton yang dikutip Moleong (2000), analisis data adalah mengatur uraian data, mengkategorikannya ke dalam pola, kategori dan satuan uraian dasar. Proses analisis data dimulai dengan membaca keseluruhan data yang diperoleh dari berbagai sumber seperti hasil belajar siswa, catatan lapangan, wawancara yang selanjutnya data dikelompokkan berdasarkan data kualitatif dan kuantitatif. Data kualitatif yang sudah dikelompokkan kemudian diubah menjadi kalimat-kalimat bermakna. Sedangkan data hasil tes akhir siklus dianalisis secara kualitatif. Penilaian akan dilakukan sesuai dengan pedoman pernskoran tes kemampuan pemahaman konsep matematika. Skor yang diperoleh pada setiap akhir siklus kemudian diubah menjadi nilai tes akhir siklus dengan cara:

$$
\text { Nilai tes akhir siklus }=\frac{\sum \text { skor yang diperoleh }}{\text { skor maksimum }} \times 100
$$

Tabel 2 Pedoman Penskoran Kemampuan Pemahaman Konsep Matematika

\begin{tabular}{|c|c|c|}
\hline $\begin{array}{l}\text { Indikator Pemahaman } \\
\text { Konsep }\end{array}$ & Skor & Keterangan \\
\hline \multirow{5}{*}{$\begin{array}{l}\text { Menyatakan ulang sebuah } \\
\text { konsep }\end{array}$} & 0 & Tidak menulis jawaban \\
\hline & 1 & Hanya menuliskan informasi yang diketahui \\
\hline & 2 & $\begin{array}{l}\text { Menyatakan ulang sebuah konsep namun penejelasan kurang } \\
\text { memuaskan. }\end{array}$ \\
\hline & 3 & $\begin{array}{l}\text { Menyatakan konsep tetapi masih kurang lengkap tetapi mengarah } \\
\text { pada jawaban benar }\end{array}$ \\
\hline & 4 & Jawaban benar dan lengkap \\
\hline \multirow{5}{*}{$\begin{array}{l}\text { Mengklasifikasikan objek } \\
\text { menurut sifat-sifat tertentu } \\
\text { sesuai dengan konsepnya }\end{array}$} & 0 & Tidak menulis jawaban \\
\hline & 1 & Hanya menuliskan informasi yang diketahui \\
\hline & 2 & Terdapat beberapa kesalahan dalam mengklasifikasikan objek \\
\hline & 3 & $\begin{array}{l}\text { Kurang lengkap dalam pengklasifikasian, tetapi sudah mengarah } \\
\text { pada jawaban benar }\end{array}$ \\
\hline & 4 & Mengklasifikasikan semua objek dengan benar dan lengkap \\
\hline
\end{tabular}




\begin{tabular}{|c|c|c|}
\hline \multirow{5}{*}{$\begin{array}{l}\text { Memberikan contoh dan bukan } \\
\text { contoh dari suatu konsep }\end{array}$} & 0 & Tidak menulis jawaban \\
\hline & 1 & Hanya menuliskan informasi yang diketahui \\
\hline & 2 & $\begin{array}{l}\text { Terdapat beberapa kesalahan dalam memberikan contoh dan } \\
\text { bukan contoh dari suatu konsep }\end{array}$ \\
\hline & 3 & $\begin{array}{l}\text { Kurang lengkap dalam memberikan contoh dan bukan contoh, } \\
\text { tetapi sudah mengarah pada jawaban benar }\end{array}$ \\
\hline & 4 & Jawaban benar dan lengkap \\
\hline \multirow{5}{*}{$\begin{array}{l}\text { Menyajikan konsep dalam } \\
\text { berbagai bentuk representasi } \\
\text { matematis }\end{array}$} & 0 & Tidak menulis jawaban \\
\hline & 1 & Hanya menuliskan informasi yang diketahui \\
\hline & 2 & $\begin{array}{l}\text { Salah menyajikan konsep kedalam bentuk-bentuk representasi } \\
\text { matematika }\end{array}$ \\
\hline & 3 & $\begin{array}{l}\text { Kurang lengkap dalam menyaikan konsep dalam bentuk } \\
\text { matematika yang lain namun sudah mengarah pada jawaban benar }\end{array}$ \\
\hline & 4 & $\begin{array}{l}\text { Menyajikan konsep dalam berbagai bentuk representasi } \\
\text { matematika dengan benar dan lengkap }\end{array}$ \\
\hline \multirow{5}{*}{$\begin{array}{l}\text { Mengembangkan syarat perlu } \\
\text { atau syarat cukup dari suatu } \\
\text { konsep }\end{array}$} & 0 & Tidak menulis jawaban \\
\hline & 1 & Hanya menuliskan informasi yang diketahui \\
\hline & 2 & $\begin{array}{l}\text { Menunjukkan pengembangan terhadap sebagian besar syarat perlu } \\
\text { atau syarat cukup }\end{array}$ \\
\hline & 3 & $\begin{array}{l}\text { Menunjukkan pengembangan terhadap konsep dan penjelasan } \\
\text { efektif }\end{array}$ \\
\hline & 4 & $\begin{array}{l}\text { Menunjukkan pengembangan yang lebih terhadap syarat perlu } \\
\text { atau syarat cukup }\end{array}$ \\
\hline \multirow{5}{*}{$\begin{array}{l}\text { Menggunakan dan } \\
\text { memanfaatkan serta memilih } \\
\text { prosedur atau operasi tertentu }\end{array}$} & 0 & Tidak menulis jawaban \\
\hline & 1 & Hanya menuliskan informasi yang diketahui \\
\hline & 2 & Tidak menggunakan prosedur atau operasi dan jawaban benar \\
\hline & 3 & $\begin{array}{l}\text { Menggunakan prosedur atau operasi yang benar dan hasil sebagian } \\
\text { benar }\end{array}$ \\
\hline & 4 & Menggunakan prosedur atau operasi yang benar dan hasil benar \\
\hline \multirow{5}{*}{$\begin{array}{l}\text { Mengaplikasikan konsep dan } \\
\text { algoritma dalam pemecahan } \\
\text { masala }\end{array}$} & 0 & Tidak menulis jawaban \\
\hline & 1 & Hanya menuliskan informasi yang diketahui \\
\hline & 2 & Menulis jawaban namun salah menggunakan konsep \\
\hline & 3 & $\begin{array}{l}\text { Mengetahui konsep yang sesuai tetapi tidak bisa menuliskannya } \\
\text { dalam algoritma penyelesaian masalah }\end{array}$ \\
\hline & 4 & $\begin{array}{l}\text { Mengetahui konsep yang sesuai dan dapat menuliskannya dalam } \\
\text { algoritma pemecahan masalah serta mendapatkan jawaban yang } \\
\text { benar }\end{array}$ \\
\hline
\end{tabular}

\section{HASIL DAN DISKUSI}

\section{Hasil}

Berdasarkan hasil penelitian tindakan kelas di kelas VIII-1 SMP Bhakti Nusantara dengan model Numbered Heads Together (NHT) yang bertujuan untuk meningkatkan pemahaman konsep matematika telah mengalami peningkatan. Dengan membandinngkan hasil dari data-data yang diperoleh selama penenlitian. Penelitian ini berlangsung selama tiga siklus. Kemampuan pemahaman konsep matematika siswa meningkat dikarenakan terlaksananya tahapan demi tahapan model pembelajaran tipe NHT dengan cukup baik meski belum sempurna, terutama dalam manajemen waktu dan memaksimalkan tahapan tertentu pada proses pembelajaran. 


\section{Hasil penelitian pada tahap numbering}

Siswa sudah mulai mengkondisikan dirinya sendiri untuk duduk bersama kelompok yang telah ditentukan. Meski pada awalnya ada beberapa siswa mengeluh dan meminta guru untuk mengganti kelompok, akan tetapi siswa tetap bertanggung jawab untuk melanjutkan diskusi kelompoknya. Guru juga memastikan seluruh siswa memiliki nomor yang berbeda dengan tiap anggota kelompoknya.

\section{Hasil penelitian pada tahap questioning}

Guru dibantu oleh participant observer untuk memberikan LAS kepada seluruh kelompok. Guru juga memastikan seluruh kelompok telah mendapatkan LAS. Tahapan ini tidak mengalami hambatan yang berarti pada setiap siklusnya

\section{Hasil penelitian pada tahap heads together}

Siswa berdiskusi bersama dengan kelompok yang telah ditentukan sebelumnya. Banyak kelompok yang masih terlihat kurang nyaman dalam berdiskusi dan terlihat pasif dalam berdiskusi pada siklus I. Pada siklus II dan siklus III guru memberikan motivasi dan memberitahu pentingnya kerjasama dalam proses diskusi kelompok sehingga diskusi kelompok menjadi lebih aktif.

\section{Hasil penelitian pada tahap call out}

Guru memanggil kelompok dan nomor secara acak untuk mempresentasikan hasil diskusi kelompoknya di depan kelas. Pada tahap ini tidak ada hambatan yang berarti. Siswa yang yang terpanggil tidak ada yang menolak untuk maju, semua murid yang terpilih bertanggung jawab untuk mempresentasikan hasil diskusi di depan kelas.

\section{Hasil penelitian pada tahap answering}

Siswa mempresentasikan hasil diskusi di depan kelas. Pada siklust I siswa yang tidak mempresentasikan banyak yang tidak memperhatikan temannya yang sedang presentasi di depan kelas. Kemudian dilakukan perbaikan pada siklus II dengan menghimbau murid untuk memperhatikan dan mendengarkan temannya yang sedang presentasi. Pada siklus II masih ada siswa yang tidak memperdulikan temannya presentasi. Kemudian dilakukan perbaikan dengan menghimbau murid untuk tenang dan memperhatikan temannya yang sedang presentasi. Pada siklus III siswa sudah belajar untuk menghargai temannya yang sedang presentasi di depan kelas.

\section{Hasil tes akhir siklus}

Pada setiap akhir siklus siswa diberikan tes berupa soal yang memuat 7 indikator pemahaman konsep matematika. Presentase hasil nilai kemampuan pemahaman konsep matematika siswa pada pra penelitian, siklus I, siklus II, dan siklus III dapat dilihat pada tabel berikut. 
Tabel 3 Perbandingan Persentase Tes Prapenelitian, Tes Akhir Siklus I, Akhir Siklus II \& Tes Akhir Siklus III

\begin{tabular}{ccccc}
\hline \multirow{2}{*}{ Kategori } & \multicolumn{4}{c}{ Persentase } \\
\cline { 2 - 5 } & $\begin{array}{c}\text { Tes } \\
\text { Prapenelitian }\end{array}$ & $\begin{array}{c}\text { Tes Akhir } \\
\text { Siklus I }\end{array}$ & $\begin{array}{c}\text { Tes Akhir } \\
\text { Siklus II }\end{array}$ & $\begin{array}{c}\text { Tes Akhir } \\
\text { Siklus III }\end{array}$ \\
\hline Sangat Kurang & $57,14 \%$ & $10,71 \%$ & $0 \%$ & $0 \%$ \\
\hline Kurang & $39,29 \%$ & $50 \%$ & $21,49 \%$ & $0 \%$ \\
\hline Cukup & $3,57 \%$ & $21,43 \%$ & $25 \%$ & $17,86 \%$ \\
\hline Baik & $0 \%$ & $14,29 \%$ & $32,14 \%$ & $46,43 \%$ \\
\hline Sangat Baik & $0 \%$ & $0 \%$ & $21,49 \%$ & $35,71 \%$ \\
\hline
\end{tabular}

Dari tabel di atas menunjukkan adanya peningkatan kemampuan pemahaman konsep matematika siswa pada setiap siklus. Terlihat bahwa siswa yang memperoleh nilai dengan kategori sangat kurang pada tes pra penelitian 57,14\%, pada siklus I mengalami penurunan menjadi 10,71\% dan pada siklus II dan siklus III tidak ada siswa dalam kategori sangat kurang. Siswa dengan kategori kurang pada pada tes pra penelitian 39,29\%, pada siklus I mengalami kenaikan menjadi 50\%, pada siklus II turun menjadi 21,49\% dan pada siklus III tidak ada siswa dalam kategori kurang. Siswa dengan kategori cukup pada pada tes pra penelitian 3,57\%, pada siklus I mengalami kenaikan menjadi 21,43\%, pada siklus II naik menjadi 25\% dan pada siklus III turun menjadi 17,86\%. Tidak ada siswa dalam kategori baik pada tes pra penelitian, pada siklus I mengalami kenaikan menjadi 14,29\%, pada siklus II naik menjadi $32,14 \%$ dan pada siklus III naik menjadi 46,43\%. Tidak ada siswa dalam kategori sangat baik pada pra penelitian dan siklus I, pada siklusi II naik menjadi 21,49\% dan pada siklus III naik menjadi $35,71 \%$. Nilai rata-rata pada setiap siklus juga mengalami peningkatan. Peningkatan rata-rata nilai kemampuan pemahaman konsep matematika siswa dapat dilihat pada Gambar 1.

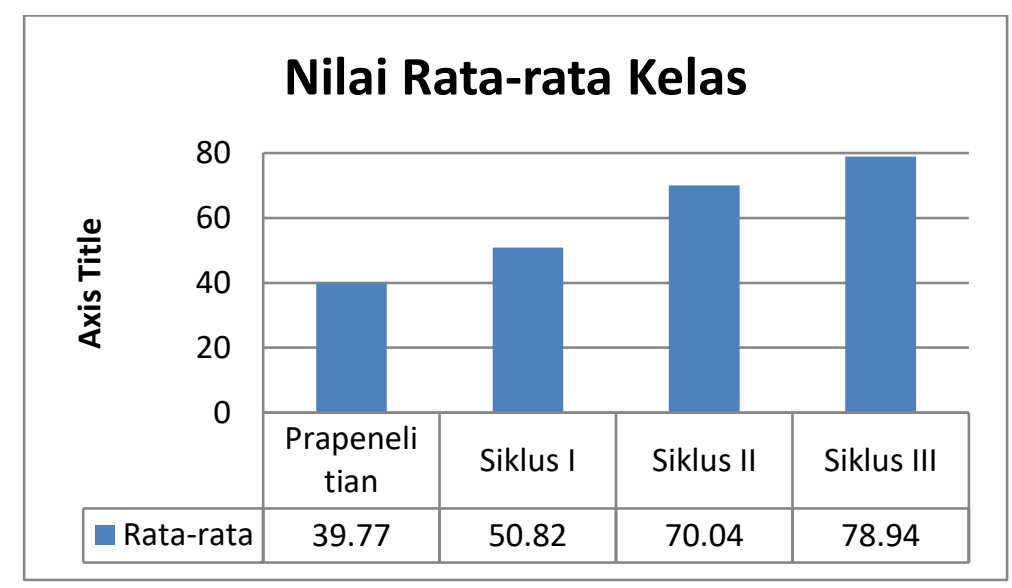

Gambar 1 Diagram Peningkatan Nilai Rata-rata Kemampuan Pemahaman Konsep Matematika pada Tes Prapenelitian, Tes Akhir Siklus I, Tes Akhir Siklus II dan Tes Akhir Siklus III

Berdasarkan data nilai tes pemahaman konsep matematika siswa pada tes pra penelitian ratarata kelas 39,77 kemudian pada siklus I mengalami peningkatan menjadi 50,82 selanjutnya pada siklus II mengalami peningkatan menjadi 70,04 dan siklus III juga mengalami peningkatan menjadi 78,94. 


\section{Pembahasan}

Berdasarkan paparan data yang sudah dijelaskan sebelumnya, kegiatan pembelajaran tipe NHT dapat meningkatkan kemampuan pemahaman konsep matematika siswa. Peningkatan kemampuan pemahaman konsep matematika siswa dapat dilihat selama proses pembelajaran, hasil tes akhir pada setiap siklus dan hasil wawancara. Penerapan model pembelajaran kooperatif tipe NHT dapat meningkatkkan kemampuan pemahaman konsep matematika siswa dikarenakan model pembelajaran ini memiliki kelebihan dibandingkan dengan model pembelajaran yang biasa diterapkan oleh guru di kelas. Model pembelajaran tipe NHT membuat siswa turut berperan aktif dalam pembelajaran. Siswa lebih antusias untuk memahami materi pembelajaran yang sedang dibahas melalui guru sebagai fasilitator, LAS dan diskusi kelompok.

Berdasarkan hasil penelitian yang telah dipaparkan, dapat disimpulkan bahwa kemampuan pemahaman konsep matematika siswa kelas VIII-1 SMPN Bhakti Nusantara Jakarta meningkat secara signifikan. Hal ini terlihat dari nilai tes akhir siklus siswa. Nilai rata-rata kemampuan pemahaman konsep matematika siswa kelas VIII-1 pada siklus I adalah 50,82. Pada siklus II rata-rata nilai kemampuan pemahaman konsep siswa meningkat menjadi 70,04. Selanjutnya pada siklus III rata-rata nilai kemampuan pemahaman konsep meningkat menjadi 78,94. Nilai rata-rata kelas berdasarkan hasil tes akhir siklus meningkat dan telah mencapai indikator keberhasilan yang telah ditetapkan.

Peningkatan kemampuan pemahaman konsep matematika juga terlihat dari jumlah siswa yang mencapai nilai kriteria ketuntasan minimal. Pada siklus I terdapat 4 siswa yang mencapai nilai kriteria ketuntasan minimal atau sebesar 14,29\% dari jumlah siswa. Pada siklus II terdapat 15 siswa yang mencapai nilai kriteria ketuntasan minimal atau sebesar 53,58\% dari jumlah siswa. Pada siklus III terdapat 23 siswa yang mencapai nilai kriteria ketuntasan minimal atau sebesar $82,14 \%$ dari jumlah siswa.

\section{KESIMPULAN}

Berdasarkan penelitian upaya meningkatkan kemampuan pemahaman konsep matematika siswa dengan menggunakan model pembelajaran kooperatif Numbered Heads Together (NHT) pada keals VIII SMP Bhakti Nusantara Jakarta, maka diperoleh kesimpulan bahwa upaya meningkatkan kemampuan pemahaman konsep matematika siswa dengan menggunakan model kooperatif tipe NHT menunjukkan peningkatan kemampuan pemahaman konsep matematika, dilihat dari analisis hasil tes setiap akhir siklus, analisis wawancara.

\section{Refferences}

Abdullah, In Hi, Berpikir Kritis Matematik, Jurnal Matematika dan Pendidikan Matematika, Vol. 2, No. 1, 2013.

Afrilianto, M, "Peningkatan Pemahaman Konsep dan Kompetensi Strategis Matematis siswa SMP dengan Pendekatan Methaphorical Thinking", Jurnal Ilmiah Program Studi Matematika STKIP 
Siliwangi Bandung, Vol. 1, No. 2, Bandung, 2012

Agoestanto, Arif dan Soviana N.P, "Keefektifan Pembelajaran matematika mengacu pada Missouri Mathematics Project Terhadap Kemampuan Pemecahan Masalah", Prosiding Seminar Matematika VII UNNES, Semarang; Universitas Negeri Semarang, 2013.

Amri, Sofan, Pengembangan dan Model Pembelajaran dalam Kurikulum 2013, Jakarta: Prestasi Pustkraya, 2013.

Danti, Dwi Puspa N., Iswahyudi Joko Suprayitno, dan Martyana Prihaswati, "Perbandingan Pembelajaran Number Heads Together dengan Team Assisted Individualization Berpendekatan Konstruktivisme Terhadap Prestasi Belajar”, Jurnal Kajian Pendidikan Matematika, Vol. 2, No. 1, Semarang, 2015.

Depdiknas, Kajian Kebijakan Kurikulum Mata Pelajaran Matematika, Jakarta: Pusat Kurikulum Balitbang Depdiknas, 2007.

Depdiknas, UU SISDIKNAS NO 20, Jakarta, 2003.

Dewi, Aprilina Kusuma, dkk, "Penerapan Model Numbered Heads Together (NHT) Dengan Media Visul Dalam Peningkatan Pembelajaran IPS Tentang Kegiatan Jual Beli Pada Siswa Kelas IIIA SDN 1 Bojongsari Tahun Ajaran 2016/2017”, Kalam Cendekia PGSD Kebumen, Vol. 5, No. 5.1, Solo, 2017.

Dimyati dan Mudijiono, Belajar dan Pembelajaran, Jakarta: Rineka Cipta, 2010.

Ilyasari, Astia, dkk, "Pengaruh Model Pembelajaran Kooperatif Tipe NHT terhadap Pemahaman

Konsep Matematis Siswa", Jurnal Pendidikan Matematika Universitas Lampung, Vol. 1, No. 7, Lampung, 2013.

Isjoni, Cooperative Learning, Bandung; Alfabeta, 2013.

Isjoni, Pembelajaran Kooperatif: Meningkatkan Kecerdasan Komunikasi Antar Peserta Didik, Yogyakarta; Pustaka Belajar, 2012.

Jihad, Asep dan Abdul Haris, Evaluasi Pembelajaran, Yogyakarta: Multi Pressindo, 2012.

Kamus Besar Bahasa Indonesia, Tersedia : https://kbbi.web.id/konsep

Kamus Besar Bahasa Indonesia, Tersedia : https://kbbi.web.id/paham.

Kesumawati, Nila, "Pemahaman Konsep Matenatik dalam Pembelajaran Matematika", Prosiding Seminar Nasional Matematika dan Pendidikan Matematika, Yogyakarta, 2008.

Kunandar, Langkah Mudah Penelitian Tindakan Kelas Sebagai Pengembangan Profesi Guru, Jakarta; PT. Raja Grafindo Persada.

Lestari, Karunia Eka dan M. Ridwan Yudhanegara, Penelitian Pendidikan Matematika, Bandung: Refika Aditama, 2015.

Mulyati, Psikologi Belajar, Yogyakarta; Andi Offset, 2005.

Moleong, Lexy J., Metodologi Penelitian Kualitatif, Bandung; Rosda, 2013.

Rusman, Model-model Pembelajaran: Mengembangkan Profesionalisme Guru Edisi Kedua, Jakarta; Rajagrafindo Persada, 2016.

Sari, Nyoman Riski Utami, dkk, "Pengaruh Model Pembelajaran Missouri Mathematics Project terhadap Kemampuan Menyelesaikan Soal Cerita Matematika Ditinjau dari Kemampuan Verbal", e-Journal Program Pascasarjana Universitas Pendidikan Ganesha Program Studi Pendidikan Dasar, Vol. 4, Singaraja, 2014.

Sudijono, Anas, Pengantar Evaluasi Pendidikan, Jakarta: Raja Grafindo Persada, 2011.

Suprijono, Agus, Cooperative Learning: Teori dan Aplikasi PAIKEM, Yogyakarta; Pustaka Belajar, 2013.

Suprijono, Agus, Model-model Pembelajaran Emansipatoris, Yogyakarta; Pustaka Belajar, 2016.

Suryadi, Didi, Pendidikan Matematika, Jurnal, Bandung; Universitas Pendidikan Indonesia.

Trianto, Mendesain Model Pmebelajaran Inovatif Progresif: Konsep, Landasan, dan Implementasinya pada Kurikulum Tingkat Satuan Pendidikan (KTSP), Jakarta; Kencana Prenada Media Group, 2010.

Winkel, Psikologi Pengajaran, Yogyakarta: Media Abadi, 2007. 
How to cite : Nur, M. A., Aris, H. W., \& Ratna, W., 2020. Upaya Meningkatkan Kemampuan Pemahaman Konsep Matematika Siswa dengan Menggunakan Model Pembelajaran Kooperatif Tipe Numbered Heads Together (NHT) pada Kelas VIII SMP Bhakti Nusantara Jakarta. Jurnal Riset Pendidikan Matematika Jakarta. 2(1). 25-45. https://doi.org/10.21009/jrpmj.v2i1.12124

To link to this article: https://doi.org/10.21009/jrpmj.v2i1.12124 